УДК 355.41

Володимир Олександрович Дачковський (кандидат технічних наук, доцент) ${ }^{1}$ Михайло Анатолійович Стрельбіцький (доктор технічних наук, доцент) ${ }^{2}$

\author{
${ }^{1}$ Національний університет оборони Украйни імені Івана Черняховського, Київ, Украӥна \\ ${ }^{2}$ Національна академія Державної прикордонної служби імені Богдана Хмельницького
}

\title{
МАТЕМАТИЧНА МОДЕЛЬ ФУНКЦІОНУВАННЯ СИСТЕМИ ВІДНОВЛЕННЯ ОЗБРОЄННЯ ТА ВІЙСЬКОВОЇ ТЕХНІКИ
}

\begin{abstract}
Аналіз виконання завдань військовими частинами (підрозділами) в локальних війнах, збройних конфліктах під час виконання завдань у Міжнародних операчіях з підтримання миру $і$ безпеки дозволяє стверджувати, щуо одним із основних чинників, які впливають на успіх у виконанні завдань є наявність працездатних зразків озброєння та військової техніки. При иььому, одним із основних джерел надходження у військові частини (підрозділи) працездатних зразків озброєння та військової техніки в ході ведення бойових дій $\epsilon$ повернення їх із стаиіонарних та рухомих ремонтно-відновлювальних військових частин (підрозділів) після проведення ремонтно-відновлювальних робіт.

Розбудова системи логістики у Збройних Силах Украӥни на усіх рівнях ієрархї вимагає пошуку нових методичних підходів щчодо забезпечення військ (сил), а саме щзодо підвищення ефективності виконання завдань з відновлення пошкоджених зразків озброєння та військової техніки.

Тому в роботі запропоновано математичну модель оцінювання ефективності функціонування системи відновлення озброєння та військової техніки $і$ забезпечення матеріальними засобами за величиною імовірності виконання комплексу робіт, які виконуються за заданий час. Для иього використано напівмарковську модель функиіонування підсистеми відновлення озброєння та військовоі техніки і забезпечення матеріальними засобами в загальній системі логістики Збройних Силах України.

Для визначення показників ефективності функиіонування системи логістики, було задано, щзо у початковий момент часу система перебуває у відповідному стані. Якщо із одного стану відбувається перехід у інший, то в изьому стані система перебуває випадковий час із довільною функиією розподілу.

Таким чином, можна дати відповіді на питання відносно функціонування системи логістики, зокрема щчодо часу перебування у відповідній множині станів, часу функціонування до моменту переходу у наступний стан. Перехід системи із одного стану у інший відбувається з ймовірністю. Аналогічно визначено стачіонарні імовірності перебування засобів відновлення озброєння та військової техніки та системи логістики у всіх решта станах.
\end{abstract}

Ключові слова: озброєння та військова техніка, відновлення, функиіонування, математична модель, забезпечення, матеріальні засоби.

\section{Вступ}

Розвиток сил логістики та набуття ними спроможностей щодо забезпечення дій військ (сил) під час проведення міжвидових, об'єднаних операцій (бойових дій) $є$ одним із пріоритетів розвитку ЗС України. На даний час відбувається розбудова системи логістики на усіх рівнях iєрархії (стратегічний, оперативний та тактичний) iз розробленням нормативних документів, зміною організаційно-штатних структур та перерозподілом повноважень і функцій.

В той же час, необхідно зауважити, що система логістики займає одне 3 важливих місць в сучасних операціях (бойових діях), а саме, на перший план виступає підсистема відновлення пошкоджених зразків озброєння та військової техніки (ОВТ).

Постановка проблеми. В галузі відновлення озброєння та військової техніки (ОВТ) одним із найбільш складних проблемних питань сьогодення $\epsilon$ своєчасне виявлення пошкодженого зразка ОВТ їх евакуація і своєчасний якісний ремонт [1-2]. Забезпечення знаходження військових частин (підрозділів) в постійному боєздатному стані досягається комплексним виконанням заходів 3 відновлення пошкоджених зразків ОВТ, забезпечення матеріальними засобами (М3) тощо [3]. Одним із ефективних шляхів досягнення мети виконання цих заходів досі залишається раціональне застосування ремонтновідновлювальних військових частин (підрозділів). При цьому, раціональні функціональні параметри застосування ремонтно-відновлювальних військових частин (підрозділів) повинні визначатись шляхом моделювання процесу відновлення пошкоджених зразків ОВТ.

Тому, питання, які пов'язані з удосконаленням методичних підходів щодо функціонування системи відновлення ОВТ є досить актуальними та потребують дослідження.

Аналіз останніх досліджень і публікацій. Дослідженню питань щодо функціонування системи логістики, а саме системи відновлення OBТ та забезпечення М3 для проведення ремонтно-відновлювальних робіт під час виконання завдань за призначенням присвячена ціла низка робіт, як вітчизняних так і закордонних 
вчених, зокрема в роботі [4] для забезпечення ефективності функціонування угруповання, а саме 3 проведення ремонтно-відновлювальних робіт, постачання МЗ за класами постачання наводиться опис моделі процесів витрачання та поповнення ресурсу і приклади результатів іiі застосування. При побудові моделі використовувався метод імітаційного моделювання, а у публікації [5] розглянуто задачу формування напрямку розвитку автоматизованих систем оброблення інформації i управління організаційного типу та алгоритм іiі розв'язання. В літературних джерелах [6] запропонована побудова дискретної динамічної математичної моделі процесу забезпечення М3 на основі структури бухгалтерського обліку, яка включає процеси закупівлі, складування і передачі на виробництво сировини, матеріалів i комплектуючих, а робота [7] стосується дослідження причин низької ефективності основних моделей складської логістики. Проведено аналіз побудови моделей управління запасами та визначені умови ї застосування. Деякі аспекти даної проблематики розглянуті у роботі [8] яка присвячена теоретичним аспектам розроблення математичних моделей інтелектуальної інформаційної системи, а у робота [9] присвячена впровадженню інтегрованої логістичної підтримки життєвих циклів зразків озброєння та військової техніки, які проектуються, виробляються, експлуатуються та утилізуються в Україні. Окремі аспекти даної проблематики викладені в роботі [10], яка присвячена вивченню процесу функціонування системи відновлення бронетанкового озброєння і техніки при виконанні військовими частинами завдань за призначенням та створенню системи підтримки прийняття рішення щодо відновлення бронетанкового озброєння і техніки в умовах часово-просторових показників. Опрацювання цієї проблеми розглянуто також у публікації [11] яка присвячена визначенню пріоритетних напрямків створення автоматизованої системи управління угрупуванням військ, а у роботі [12] запропонований підхід до моделювання оптимальних параметрів управління логістичними розподільчими системами який направлений на удосконалення системи показників. В роботі [13] запропоновано математичну модель управління запасами 3 урахуванням їх поповнення яка спрямована зменшення логістичних витрат, а у робота [14] присвячена створенню автоматизованої системи управління технічним забезпеченням. Глибоке опрацювання цієї проблеми відображене у роботі [15] в якій проведено аналіз концепції сите центричної війни, виявленні взаємозв'язки концепції з інформаційнотехнічною прогресом, тенденцією розвитку нового озброєння, тощо. В роботі [16] запропоновано, що в основу формування функціональної автоматизованої системи управління повинні бути покладені моделі і методи програмно-цільового управління, які представляють сукупність функціонально-алгоритмічних і інформаційнорозрахункових засобів для розв'язання задач спрямованих на підтримання і відновлення технічної готовності ОВТ. Також опрацювання даної проблематики було у [17] де представлено аналіз запропонованих моделей виробничого розподілу та описані основні характеристики вибраних моделей, а у роботі [18] враховуючи складність більшості складів запропонована система управління складом, яка працює динамічно 3 даними в реальному часі, а у [19] запропонована модель змішаного чисельного програмування для інтеграції складських рішень щодо запасів та транспортування для зведення до мінімуму затрати на розподіл.

Мета статті. Виходячи із вищезазначено, мета статті полягає у розробленні математичної моделі процесу відновлення ОВТ для узагальнення якої використано напівмарківський процес.

\section{Виклад основного матеріалу дослідження}

Ефективність відновлення ОВТ і забезпечення M3 в інтересах угрупування військ будемо оцінювати за величиною імовірності виконання комплексу робіт, які виконуються за заданий час.

Для оцінювання впливу на значення якісних показників функціонування угрупування військ в умовах ведення операції (бойових дій) за рахунок своєчасного відновлення ОВТ можна скористатись підходом, запропонованим у [20].

Для цього, розглянемо напівмарковську модель функціонування підсистеми відновлення ОВТ та забезпечення М3 в загальній системі логістики 3С України. Орієнтовний граф переходів системи $\mathrm{S}=\left\{\mathrm{S}_{1}, \mathrm{~S}_{2}, \ldots, \mathrm{S}_{14}\right\} \quad 3$ одного стану в інший під час відновлення пошкоджених зразків ОВТ наведено на рис. 1.

У загальному підході постановка задачі щодо моделювання функціонування системи відновлення ОВТ та забезпечення МЗ може бути здійснена у такий спосіб. Нехай система S перебуває в одному із станів:

$\mathrm{S}_{1}$ - система розгорнута готова до виконання завдання;

$\mathrm{S}_{2}$ - до системи надійшли заявки щодо потреби у відновленні пошкоджених зразків ОВТ;

$\mathrm{S}_{3}$ - орган управління прийняв рішення та призначив засоби для проведення ТхР, евакуації та ремонту ОВТ для виконання завдань з відновлення OBT із врахуванням рівня отриманих пошкоджень зразками ОВТ;

$\mathrm{S}_{4}$ - призначені засоби ТхР, евакуації та ремонту висунулись до районів виконання завдань;

$\mathrm{S}_{5}$ - засоби технічної розвідки виявили пошкоджений зразок ОВТ;

$\mathrm{S}_{6}$ - засоби ТхР визначили рівень пошкодження зразка ОВТ, обсяг робіт з ремонту, маршрут евакуації, тощо;

$\mathrm{S}_{7}$ - засоби ТхР прийняте рішення щодо порядку евакуації або ремонту ОВТ на місці;

$\mathrm{S}_{8} \quad$ - засоби евакуації транспортують пошкоджений зразок ОВТ на ЗППМ; 
$\mathrm{S}_{9}$ - засоби ремонту ремонтують зразок ОВТ на місці виявлення;

$\mathrm{S}_{10}$ - пошкоджений зразок ОВТ ремонтують на ЗППМ;

$\mathrm{S}_{11}$ - засоби ремонту використали наявні М3;

$\mathrm{S}_{12}$ - здійснена доповідь органу управління щодо поповнення М3;

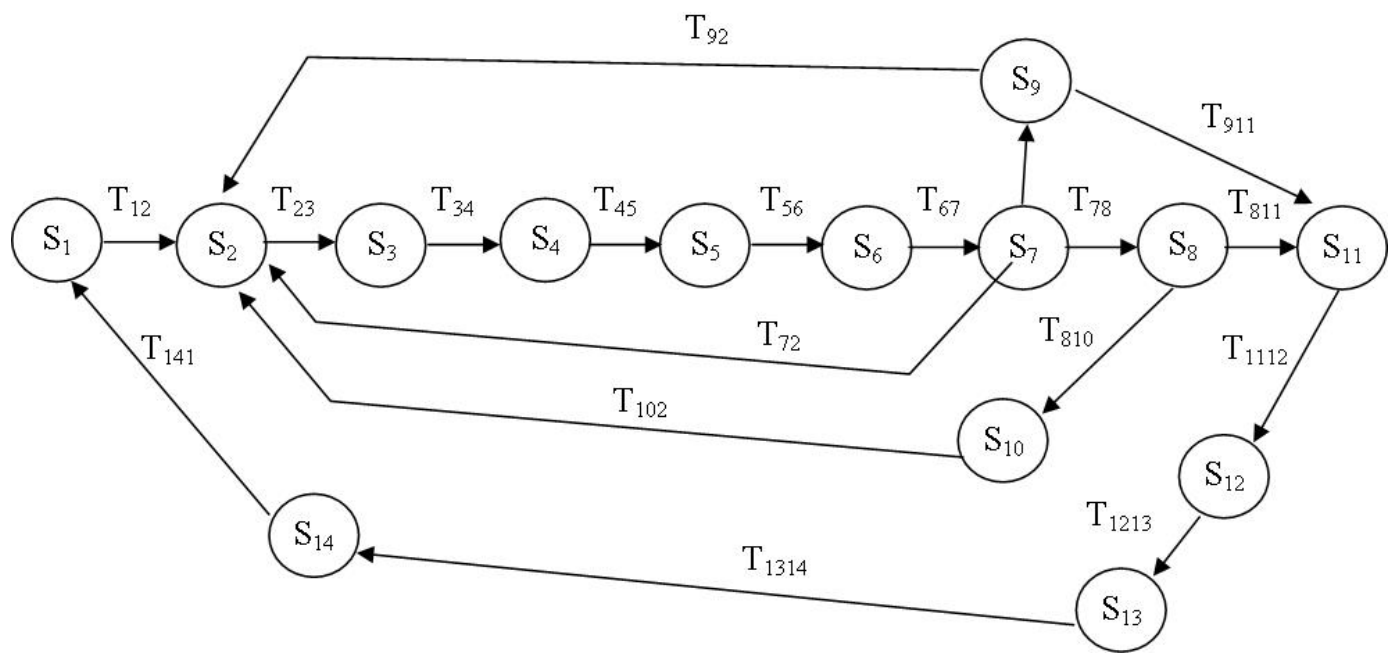

Рис. 1 Орієнтовний граф станів процесу відновлення ОВТ

Представлений на рис. 1 розмічений граф відображає всю кількість можливих станів процесу відновлення ОВТ характеристики кожного з яких істотно залежать від характеру та обсягів завдань 3 відновлення ОВТ.

Кінцевою метою аналізу такої напівмарківської моделі є оцінювання можливого впливу на обсяги завдань 3 відновлення ОВТ, які виникають перед системою логістики підсистем ТхР, евакуації, ремонту або забезпечення МЗ.

Як вказувалось вище, для того щоб задати напівмарківську модель повинні бути відомі елементи матриці функцій розподілу випадкових інтервалів часу перебування системи в кожному стані $\mathrm{F}(\mathrm{t})$ і матриці ймовірностей переходів іiі зі стану в стан $\mathrm{P}$.

Для визначення показників ефективності функціонування системи логістики, як станів $\mathrm{S}_{\mathrm{i}}$ при умові, що у початковий момент часу система перебувала у стані $\mathrm{S}_{\mathrm{j}}=(\mathrm{i}, \mathrm{j}=1,2, \ldots, 14)$

Як відомо, подібна задача розглядалась у роботах [21], де моделювання функціонування засобів відновлення ОВТ запропоновано проводити за допомогою марковського процесу із дискретною множиною станів та безперервним часом.

На відмінну від робіт [22] для системи логістики будемо вважати, що перехід системи $\mathrm{S}$ iз одного стану в інший відбувається наступним чином:

$\mathrm{y}$ початковий момент часу $\mathrm{t}=0$ система перебуває у стані $\mathrm{S}_{1}$ деякий випадковий час $\mathrm{Q}_{1}$ (відлік часу починається 3 моменту початку розгортання системи логістики.) Тобто цей час, який система $\mathrm{S}$ перебуває у стані $\mathrm{S}_{1}$ до переходу у стан $\mathrm{S}_{2} 3$ довільною функцією розподілу $\mathrm{F}_{12}(\mathrm{t})$;
$\mathrm{S}_{13}$ - орган управління прийняв рішення та поставив завдання щодо поповнення М3;

$\mathrm{S}_{14}$ - МЗ поповнено;

$\mathrm{T}_{\mathrm{ij}}$ - значення часу перебування системи логістики або іiі елементів (засобів відновлення) в стані $i$ до переходу його в стан $\mathrm{j}(\mathrm{i}, \mathrm{j} \in 1,7)$ 
ймовірності того, що напівмарківська модель $\mathrm{v}(\mathrm{t})$ перебуває у стані $\mathrm{S}_{\mathrm{j}}$ за умови, що час перебування менший, ніж $\mathrm{t}$.

Таким чином, співвідношення (3) та напівмарковська матриця (2) дозволяють дати відповіді на цілу низку питань відносно функціонування системи логістики, зокрема щодо часу перебування у відповідній множині станів, часу функціонування до моменту переходу у наступний стан тощо. Відмітимо також, якщо час перебування системи $\mathrm{S}$ у кожному стані $\mathrm{S}_{\mathrm{i}},(\mathrm{i}=1,2, \ldots 14)$ буде розподілено за показовим законом, тоді із розглянутих співвідношень витікають формули для розрахунку ймовірностей, які одержані в роботі [26].

Визначимось із законом розподілу часу перебування системи $\mathrm{S}$ у кожному із можливих станів $S_{i},(i=1,2, \ldots 14)$.

При прийнятих припущеннях та отриманих даних матриця $\mathrm{F}(\mathrm{t})$ має вигляд

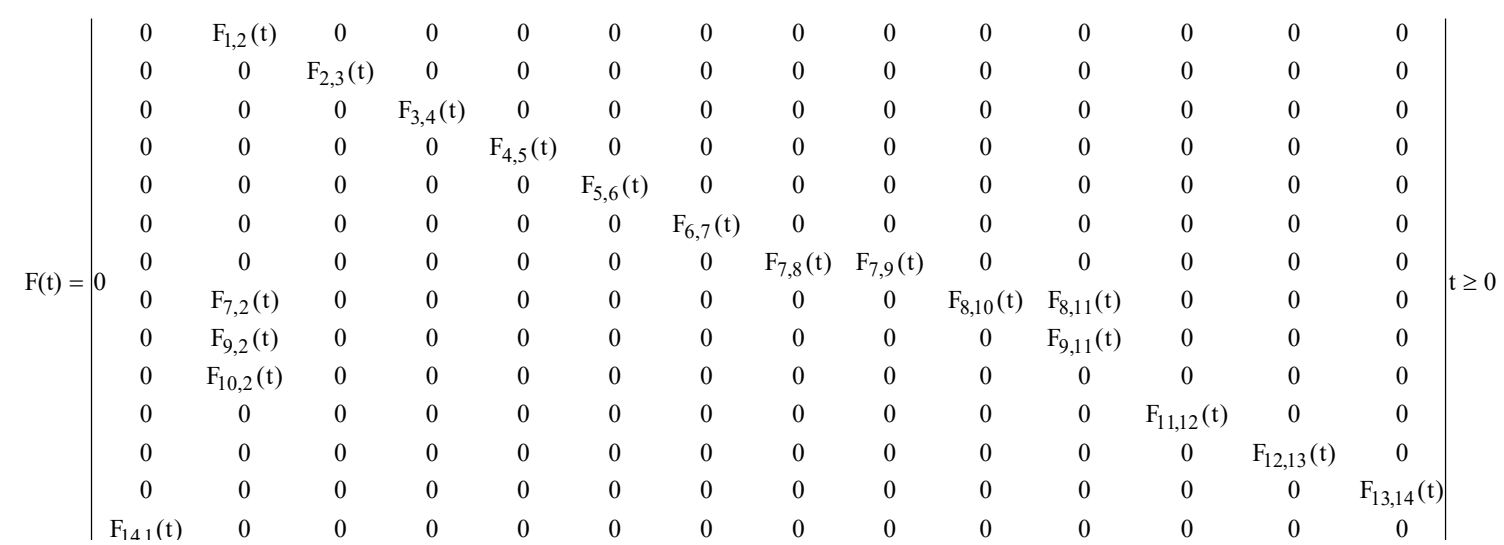

Елементи матриці розраховуються із співвідношень [27]

$$
\begin{gathered}
F_{2,3}(t)=F_{6,7}(t)=F_{7,9}(t)=F_{8,10}(t)= \\
=F_{7,2}(t)=F_{9,2}(t)=F_{10,2}(t)=F_{11,12}(t)= \\
F_{12,13}(t)=\frac{1}{\sigma \sqrt{2 \pi}} \int_{0}^{t} e^{\frac{(\tau-m)^{2}}{2 \sigma^{2}}} d \tau \\
F_{1,2}(t)=1-e^{-\lambda_{1} t} \\
F_{3,4}(t)=1 \quad e^{\lambda_{2} t} \\
F_{4,5}(t)=1 \quad e^{\lambda_{3} t} \\
F_{5,6}(t)=1 \quad e^{\lambda_{4} t} \\
F_{7,8}(t)=1 \quad e^{\lambda_{5} t} \\
F_{8,11}(t)=1 \quad e^{\lambda_{6} t}
\end{gathered}
$$

$$
\begin{aligned}
& \mathrm{F}_{9,11}(\mathrm{t})=1 \quad \mathrm{e}^{\lambda_{7} \mathrm{t}} \\
& \mathrm{F}_{13,14}(\mathrm{t})=1 \quad \mathrm{e}^{\lambda_{8} \mathrm{t}} \\
& \mathrm{F}_{14,1}(\mathrm{t})=\left\{\begin{array}{l}
1, \text { при } \mathrm{t}_{\text {зад }} \geq \mathrm{T}_{18}, \\
\frac{\mathrm{t}_{\text {зад }}}{\mathrm{T}_{18}}, \text { при } \mathrm{t}_{\text {зад }}<\mathrm{T}_{18}
\end{array}\right.
\end{aligned}
$$

У формулах (7-15) прийняті наступні позначення:

$\mathrm{m}, \sigma$ - середньоквадратичне відхилення i математичне очікування випадкового часу перебування системи у визначеному стані;

$\lambda_{\mathrm{i}}-$ інтенсивність процесів переходу системи логістики або ії елементів у наступний стан;

$\mathrm{t}_{\text {зад }}, \mathrm{T}_{18}$ - заданий та середній час поповнення M3

Значення елементів матриці $P$

$$
P=\left|\begin{array}{cccccccccccccc}
0 & 1 & 0 & 0 & 0 & 0 & 0 & 0 & 0 & 0 & 0 & 0 & 0 & 0 \\
0 & 0 & P_{2,3} & 0 & 0 & 0 & 0 & 0 & 0 & 0 & 0 & 0 & 0 & 0 \\
0 & 0 & 0 & P_{3,4} & 0 & 0 & 0 & 0 & 0 & 0 & 0 & 0 & 0 & 0 \\
0 & 0 & 0 & 0 & P_{4,5} & 0 & 0 & 0 & 0 & 0 & 0 & 0 & 0 & 0 \\
0 & 0 & 0 & 0 & 0 & P_{5,6} & 0 & 0 & 0 & 0 & 0 & 0 & 0 & 0 \\
0 & 0 & 0 & 0 & 0 & 0 & P_{6,7} & 0 & 0 & 0 & 0 & 0 & 0 & 0 \\
0 & 0 & 0 & 0 & 0 & 0 & 0 & P_{7,8} & P_{7,9} & 0 & 0 & 0 & 0 & 0 \\
0 & P_{7,2} & 0 & 0 & 0 & 0 & 0 & 0 & 0 & P_{8,10} & P_{8,11} & 0 & 0 & 0 \\
0 & P_{9,2} & 0 & 0 & 0 & 0 & 0 & 0 & 0 & 0 & P_{9,11} & 0 & 0 & 0 \\
0 & P_{10,2} & 0 & 0 & 0 & 0 & 0 & 0 & 0 & 0 & 0 & 0 & 0 & 0 \\
0 & 0 & 0 & 0 & 0 & 0 & 0 & 0 & 0 & 0 & 0 & P_{11,12} & 0 & 0 \\
0 & 0 & 0 & 0 & 0 & 0 & 0 & 0 & 0 & 0 & 0 & 0 & P_{12,13} & 0 \\
0 & 0 & 0 & 0 & 0 & 0 & 0 & 0 & 0 & 0 & 0 & 0 & 0 & P_{13,14} \\
F_{14,1}(t) & 0 & 0 & 0 & 0 & 0 & 0 & 0 & 0 & 0 & 0 & 0 & 0 & 0
\end{array}\right|
$$


Можуть бути отримані за формулою

$$
P_{i j}=\frac{1 / T_{i j}}{\sum_{j=1}^{J} 1 / T_{i j}}
$$

де $\mathrm{T}_{\mathrm{ij}}$ - середній час переходу з одного стану до іншого.

При наявності даних про значення елементів матриць F і P можна визначити середнє значення часу перебування в одному із станів.

Значення стаціонарної імовірності знаходження засобів відновлення ОВТ в загальній системі логістики у цьому стані можливо розрахувати за формулою [27]

$$
\Pi_{\mathrm{v}}=\frac{\mathrm{D}_{0}}{\sum_{\mathrm{K}=0}^{\mathrm{m}} \mathrm{D}_{\mathrm{K}}}
$$

де $\mathrm{D}_{0}\left(\mathrm{D}_{\mathrm{K}}\right)$ - мінор матриці, отриманий шляхом викреслення де $\mathrm{v}-\mathrm{i}(K-\mathrm{i})$ строки i v-го ( $K$-го) стовпця.

Аналогічно можна визначити стаціонарні імовірності $\Pi_{\mathrm{K}}, \mathrm{K} \in$,m перебування засобів відновлення ОВТ та системи логістики у всіх решта станах.

Потім, використовуючи співвідношення (18) розраховується безумовне математичне очікування $\mu_{\mathrm{K}}, \mathrm{K} \in, \mathrm{m}$ часу перебування системи логістики та іiі елементів (засобів комплексів призначених для відновлення ОВТ) в кожному $3 \mathrm{~m}$ станів, в тому числі і стані $\mathrm{V}$ та визначається середній час до першого переходу засобу відновлення ОВТ системи логістики зі стану $\mathrm{v}$ до стану $\mathrm{v}^{\prime}$

$$
1_{\mathrm{vv}^{\prime}}=\frac{1}{\Pi_{\mathrm{v}}} \sum_{\mathrm{K}=0}^{\mathrm{m}} \Pi_{\mathrm{K}} \mu_{\mathrm{K}}
$$

Тоді, середній час перебування системи логістики та іï засобів відновлення у $v$-му стані на деякому інтервалі функціонування $T_{\phi}$ буде складати величину

$$
\mathrm{t}_{\mathrm{v}}=\frac{\mu_{\mathrm{v}}}{1_{\mathrm{vv}^{\prime}}+\mu_{\mathrm{v}}} \mathrm{T}_{\phi}
$$

Такий підхід дозволить виділити конкретні напрямки удосконалення підсистеми відновлення OBТ та забезпечення М3

На підгрунті дослідження розглянутих математичних моделей за розрахунковими значеннями, вимог до показників ефективності складових системи забезпечення створеного угрупування військ за рахунок функціонування системи логістики i 1 ii елементів (засобів відновлення). Із використанням вихідних даних щодо очікуваної інтенсивності надходження вимог на обслуговування до системи, яка досліджується, визначеними вимогами до часових параметрів іï підсистем відновлення ОВТ і забезпечення МЗ є: допустимий час виконання одиничного обсягу завдань, з відновлення структурними елементами системи логістики за складністю виконуваних обсягів завдань та забезпечення поповнення М3 табл. 1.

\begin{tabular}{|c|l|c|}
\hline $\begin{array}{c}\text { Умовні } \\
\text { позначення }\end{array}$ & \multicolumn{1}{|c}{ Таблиця 1} \\
\hline $\mathrm{t}_{\text {в }}$ & $\begin{array}{l}\text { Допіст показника } \\
\text { до виконання завдання за призначенням }\end{array}$ & $\begin{array}{c}\text { Значення } \\
\text { год. }\end{array}$ \\
\hline $\mathrm{t}_{\text {ви }}$ & Допустимий час висування засобів відновлення зо району виконання завдань & 10 \\
\hline $\mathrm{t}_{\text {ТхР }}$ & Допустимий час ведення ТхР у визначеній смузі & 0,5 \\
\hline $\mathrm{t}_{1 \text { ск }}$ & Допустимий час виконання робіт 1-ї складності & 10 \\
\hline $\mathrm{t}_{2 \text { ск }}$ & Допустимий час виконання робіт 2-ї складності & 20 \\
\hline $\mathrm{t}_{\text {зск }}$ & Допустимий час виконання робіт 3-ї складності & До 100 \\
\hline $\mathrm{t}_{\mathrm{M} 3}$ & Допустимий час поповнення МЗ для в інтересах системи відновлення ОВТ & 8 \\
\hline
\end{tabular}

Однак необхідно відмітити, що вимоги до часових параметрів функціонування системи логістики, до якої надходять заявки на виконання завдань 3 відновлення різного ступеня складності, слід розглядати в якості базових, середніх за сукупністю виникнення вимог щодо відновлення OBT на тривалих інтервалах часу функціонування системи логістики. Таке усереднення дозволяє прийняти припущення стосовно того, що потоки таких вимог (заявок на обслуговування) є Пуасонівськими, тобто володіють властивістю стаціонарності. Як вказано в [28-29] при такому припущенні по заданим вимогам до часових параметрів функціонування системи логістики та іiї елементів (засобів відновлення) слід обгрунтовувати вимоги до базової структури, складу та типажу засобів відновлення ОВТ на різних рівнях ієрархї організаційно-технічної системи логістики. Проведені в [30] дослідження на підгрунті теоретичних та практичних результатів свідчить, що існуюча система відновлення ЗС України за основними параметрами, в цілому не відповідає базовим вимогам, що вимагає внесення необхідних змін до вимог, як до засобів відновлення так i до параметрів і структури системи логістики [31-32].

\section{Висновки й перспективи подальших досліджень}

На період ведення бойових дій передбачається нарощення спроможностей системи логістики 3 урахуванням підвищення вимог до іiі часових параметрів.

Вихідними даними для розрахунку сил і засобів 
такого нарощування $\epsilon$ характер i інтенсивність очікуваних обсягів завдань 3 відновлення ОВТ.

Таким чином наведені у роботі співвідношення та напівмарківська матриця дозволяють дати відповіді на низку питань відносно функціонування системи відновлення

\section{Лimepamypa}

1. Дачковський, В.О. Ярошенко, О.В. Кузнецов, І.Б. Овчаренко, І.В. Основи організачії відновлення озброєння та військової техніки. Київ, НУОУ ім. Івана Черняховського, 2019, 136 с. 2. Дачковський, В.О. Овчаренко, І.В. Ярошенко О.В. Основи евакуації озброєння та військової техніки - К.: НУОУ ім. Івана Черняховського, 2017. - 180 с. 3. Ковтуненко, А.П. Шишанов, М.А. Зубарев, В.В. Основы теории восстановления эксплуатационных свойств технических систем. К.: Книжноеиздательство НАУ, 2007, 294 с. 4. Лєнков, Є.С. Толок, І.В. Прогнозування складу i ресурсу угрупувань технічних об'єктів. Системи озброєння і військова техніка, 2018, №3(55). с. 78-84. 5. Лясковский, В.Л. Бреслер, И.Б. Алашеев, М.А. Постановка задачи формирования направлений развития автоматизированных систем организационного типа и алгоритм еe решения. Программные продукты $и$ системы, 2017, №2 (30). С. 165-171. 6. Сиразетдинов, P.T. Марков, Д.С. Математическое моделирование процесса снабжения производственного предприятия на основе регистров бухгалтерского учета. Известия Самарского научного иентра Российской академии наук, 2016, т. 18, №4(3). с. 628-633. 7. Несторенко, А.В. Математическое моделирование логистики промышленных предприятий при различных вариантах базовой информации. Технологический аудит и резервы производства, 2014, № 5/1(19). с. 69-75. 8. Подшивалова, А.В. Королева, Л.А. Панюшкина, О.В. Моделирование структурной составляющей интегрированной сапродежды. Фундаментальные исследования, 2013, №10. с. 2158-2161. 9. Скворчевський, О.Є. CALS- Концепція логістичної підтримки життєвого циклу озброєння та військової техніки: національні аспекти впровадження. Сучасні інформаційні технології у сфері безпеки та оборони, 2019, № 1 (34). с. 45-52. 10. Копашинський, С.А. Серпухов, О.В. Макогон О.А. Застосування технології "електронної хмари" для вдосконалення функціонування системи відновлення бронетанкового озброєння і техніки. Сучасні інформаційні системи, 2019, Т. 3, №4. с. 126-131. 11. Ляпин, В.P. Автоматизация и интеллектуализация управления группировками вооруженных сил. Программные продукты и системы, 2006, №1. с. 41-43. 12. Коломицева, А.О. Яковенко, В.С. Моделювання процесів оптимального управління логістичними розподільчими системами. Бізнесінформ, 2012, № 7. с. 18-21. 13. Голоскоков, К.П. Давыдов, К.А. Математическая модель технологии управления запасами компании. [Електронний ресурс]: Режим доступу:

https://cyberleninka.ru/article/n/matematicheskaya-modeltehnologii-upravleniya-zapasami-kompanii/viewer

14. Арепин Ю.И. Методология создания автоматизированных систем технического обеспечения. [Електронний ресурс]: Режим доступу: http://www.ozakaz.ru/index.php/articles/n-25-12-2007/202n27032011-17-34 15. Макаренко, С.И. Иванов М.С. Сетецентрическая война - принципы, технологии, пошкоджених зразків ОВТ у відповідній множині станів, часу функціонування до моменту втрати боєздатного стану.

Як напрямок подальших досліджень може бути розроблення моделі автоматизації функціонування системи відновлення пошкоджених зразків ОВТ.

примеры и перспективы. СПб: Наукоемкие технологии. 2018. 898 с 16. Пацкан, М.Ю. Орлов, А.М. Информационная поддержка технического обеспечения кораблей при первой операции флота. Программные продукты и системы,, 2000, №2. с. 40-42. 17. В. Fahimnia, L. Luong, R. Marian An integrated model for the optimisation of a two-echelon supply network. Journal of Achievements in Materials and Manufacturing Engineering, 2008, Vol. 31 Issue 2 December. p. 477-484. 18. Ramírez Ríos, D. Ramírez Polo, L. Jimenez Barros, M. Castro Bolaño, L. Maldonado, E. The design of a real-time warehouse management system that integrates simulation and optimization models with RFID technology. International Journal of Computer Science \& Applications (TIJCSA), 2013, Vol.(02) No.(04). 19. Pratik, J. Parikh, X.Z. and Bhanuteja S. Distribution planning considering warehousing decisions. [Electronic source]: Access mode: https://www.mhi.org/

downloads/learning/cicmhe/colloquium/2010/parikh.pdf 20. Юров, Б.Н. Исследование операций. М.: ВИА, 1990, 528 с. 21. Королюк, В.С. Турбин, А.Ф. Полумарковские процесы и их приложения. К.: Науч. Мысл., 1976, 182 с. 22. Іващука О.T. Економіко-математичне моделювання: навчальний посібник. Тернопіль: ТНЕУ《Економічна думка», 2008, 704 с. 23. Павленко П.М. Основи математичного моделювання систем і процесів: навчальний посібник. К.: Книжкове вид-во НАУ, 2013, 201 с. 24. Бурименко Ю.И. Лебедева, И.Ю. Щуровская, А.Ю. Оптимизационные методы и модели с решением задач на компьютере: учеб. пособ. Одесса, 2016, 152 с. 25. Тихомирова, А.Н. Сидоренко, Е.В.. Математические модели и методы в логистике: Учебное пособие. М.: НИЯУ МИФИ, 2010, 320 с. 26. Стеценко I.B. Моделювання систем: навчальний посібник. Черкаси: ЧДТУ, 2010, 399 с. 27. Маценко В.Г. Математичне моделювання: навчальний посібник. Чернівці: Чернівецький національний університет, 2014, 519 с. 28. Швиданенко, Г.О. Формування бізнес-моделі підприємства: навчальний посібник. К.: КНЕУ, 2013, 423 с. 29. Колодізєва, Т.О. Управління ланцюгами поставок: навчальний посібник Харків: ХНЕУ ім. С. Кузнеця, 2016, 164 с. 30. Дачковський, В.О. Коцюруба, B.I. Методика оцінювання ефективності функціонування системи відновлення озброєння та військової техніки. Сучасні інформаційні технології у сфері безпеки та оборони, 2020, №1 (37), с. 5-14. DOI:10.33099/2311-7249/2020-37-1-5-14

31. Дачковський В.O. Методика обгрунтування тактико-технічних вимог до рухомих засобів ремонту озброєння та військової техніки. Social development \& Security. 2019, 9(6), 86-101. http://doi.org/10.33445/sds.2019.9.6.7

32. Дачковський В.O. Методика обгрунтування тактико-технічних вимог до засобів евакуації озброєння та військової техніки. Social development \& Security. 2020, Vol. 10, No. 3, c. 104-113. DOI: 10.33445/sds.2020.10.3.9 


\title{
МАТЕМАТИЧЕСКАЯ МОДЕЛЬ ФУНКЦИОНИРОВАНИЯ СИСТЕМЫ ВОССТАНОВЛЕНИЕ ВООРУЖЕНИЯ И ВОЕННОЙ ТЕХНИКИ
}

\author{
Владимир Александрович Дачковский (кандидат технических наук, доцент) ${ }^{1}$ \\ Михаил Анатольевич Стрельбицький (доктор технических наук, доцент) ${ }^{2}$
}

\author{
${ }^{1}$ Национальный университет обороны Украины имени Ивана Черняховского, Киев, Украина \\ ${ }^{2}$ Национальная академия Государственной пограничной службы имени Богдана Хмельницкого
}

Анализ выполнения заданий воинскими частями (подразделениями) в локальных войнах, вооруженных конфликтах при выполнении задач в Международных операциях по поддержанию мира и безопасности позволяет утверждать, что одним из основных факторов, влияющих на успех в выполнении задач является наличие работоспособных образцов вооружения и военной техники. При этом, одним из основных источников поступления в воинские части (подразделения) исправных образцов вооружения и военной техники в ходе ведения боевых действий является возвращение их из стационарных и подвижных ремонтно-восстановительных воинских частей (подразделений) после проведения ремонтно-восстановительных работ.

Развитие системы логистики в Вооруженных Силах Украины на всех уровнях иерархии требует поиска новых методчческих подходов по обеспечению войск (сил), а именно по повышению эффективности выполнения задач по восстановлению поврежденных образиов вооружения и военной техники.

Поэтому в работе предложена математическая модель оценки эффективности функиионирования системы восстановления вооружения и военной техники и обеспечения материальными средствами по величине вероятности выполнения комплекса работ, выполняемых за заданное время. Для этого использовано полумарковскую модель функционирования подсистемь восстановления вооружения и военной техники и обеспечения материальными средствами в общей системе логистики Вооруженных Силах Украины.

Для определения показателей эффективности функционирования системы логистики, было задано, что в начальный момент времени система находится в соответствующем состоянии. Если из одного состояния происходит переход в другой, то в этом состоянии система находится случайное время с произвольной функиией распределения.

Таким образом, можно дать ответьл на вопросы относительно функционирования системы логистики, в частности по времени пребывания в соответствующем множестве состояний, времени функиионирования до момента перехода в следующее состояние. Переход системь из одного состояния в другое происходит с вероятностью. Аналогично определены стационарные вероятности нахождения средств восстановления вооружения и военной техники и системы логистики у всех остальных состояниях.

Ключевые слова: вооружение и военная техника, восстановление, функиионирование, математическая модель, обеспечение, материальные средства.

\section{MATHEMATICAL MODEL OF SYSTEM FUNCTIONING RESTORATION OF WEAPONS AND MILITARY EQUIPMENT}

\author{
Volodymyr Dachkovskyi (Candidate of Technical Sciences, Associate Professor) ${ }^{1}$ \\ Mykhailo Strelbitskyi (Doctor of Technical Sciences, Associate Professor) ${ }^{2}$
}

\begin{abstract}
${ }^{1}$ National Defence University of Ukraine named after Ivan Cherniakhovsky, Kyiv, Ukraine ${ }^{2}$ National Academy of State Border Guard Service of Ukraine name after Bohdan Khmelnitsky
\end{abstract}

Analysis of the performance of tasks by military units (subdivisions) in local wars, armed conflicts during the performance of tasks in international peacekeeping and security operations suggests that one of the main factors influencing the success of the tasks is the availability of working models of weapons and military equipment. At the same time, one of the main sources of receipt in military units (subdivisions) of working samples of armaments and military equipment during hostilities is their return from stationary and mobile repair and rehabilitation military units (subdivisions) after repair and restoration works.

The development of the logistics system in the Armed Forces of Ukraine at all levels of the hierarchy requires the search for new methodological approaches to the provision of troops (forces), namely to increase the efficiency of tasks to restore damaged weapons and military equipment.

Therefore, the paper proposes a mathematical model for evaluating the effectiveness of the system of restoration of armaments and military equipment and providing material resources by the probability of performing a set of works performed for a given time. For this purpose, a semi-Markov model of the functioning of the subsystem for the restoration of armaments and military equipment and the provision of material resources in the general logistics system of the Armed Forces of Ukraine was used.

To determine the performance of the logistics system, it was specified that at the initial time the system is 
in the appropriate state. If there is a transition from one state to another, then in this state the system is a random time with an arbitrary distribution function.

Thus, it is possible to answer questions about the functioning of the logistics system, in particular about the time spent in the appropriate set of states, the time of operation until the transition to the next state. The transition of the system from one state to another occurs with probability. Similarly, the stationary probabilities of the weapons and military equipment and logistics system in all other states are located.

Keywords: armament and military equipment, restoration, functioning, mathematical model, support, material means.

\section{References}

1. Dachkovskyi, V.O. Yaroshenko, O.V. Kuznetsov, I.B. Ovcharenko, I.V. Fundamentals of the organization of the restoration of armaments and military equipment. Kyiv, NUOU them. Ivan Chernyakhovsky, 2019, 136 p. 2. Dachkovskyi, V.O. Ovcharenko, I.V. Yaroshenko O.V. Fundamentals of evacuation of weapons and military equipment - K .: NUOU them. Ivan Chernyakhovsky, 2017. - 180 p. 3. Kovtunenko, A.P. Shyshanov, M.A. Zubarev, V.V. Fundamentals of the theory of restoration of operational properties of technical systems. K .: Knizhnoeizdatelstvo NAU, 2007, 294 p. 4. Lenkov, E.S. Tolok, I.V. Forecasting the composition and resource of groups of technical objects. Weapons systems and military equipment, 2018, №3 (55). p. 78-84. 5. Lyaskovsky, V.L. Bresler, I.B. Alasheev, M.A. Statement of the problem of formation of directions of development of the automated systems of organizational type and algorithm of its decision. Software Products and Systems, 2017, №2 (30). p. 165-171. 6. Sirazetdinov, R.T. Markov, D.S. Mathematical modeling of the supply process of a manufacturing enterprise based on accounting registers. Proceedings of the Samara Scientific Center of the Russian Academy of Sciences, 2016, vol. 18, №4 (3). p. 628-633. 7. Nestorenko, A.V. Mathematical modeling of logistics of industrial enterprises with different variants of basic information. Technological audit and production reserves, 2014, № 5/1 (19). p. 69-75. 8. Podshivalova, A.V. Koroleva, L.A. Panyushkyna, O.V. Modeling of the structural component of integrated support. Fundamental Research, 2013, №10. p. 2158-2161. 9. Skvorchevsky, O.E. CALS- Concept of logistical support of the life cycle of armaments and military equipment: national aspects of implementation. Modern Information Technologies in the Sphere of Security and Defence, 2019, № 1 (34). p. 45-52. 10. Kopashinskyi, S.A. Serpukhov, O.V. Makogon O.A. Application of "electronic cloud" technology to improve the functioning of the system of restoration of armored weapons and equipment. Modern information systems, 2019, Vol. 3, №4. p. 126-131. 11. Lyapin, V.R. Automation and intellectualization of management of groups of armed forces. Software products and systems, 2006, №1. p. 41-43. 12. Kolomytseva, A.O. Yakovenko, V.S. Modeling of processes of optimal management of logistic distribution systems. Businessinform, 2012, № 7. p. 18-21. 13. Goloskokov, K.P. Davydov, K.A. Mathematical model of the company's inventory management technology. [Electronic resource]: Access mode: https://cyberleninka.ru/article/n/matematicheskaya-modeltehnologii-upravleniya-zapasami-kompanii/viewer

14. Arepin Yu.I. Methodology for creating automated technical support systems. [Electronic resource]: Access mode: http://www.ozakaz.ru/index.php/articles/n-25-122007/202-n27032011-17-34 15. Makarenko, S.I. Ivanov M.S. Network-centric war - principles, technologies, examples and prospects. St. Petersburg: Science-intensive

technologies. 2018. 898 p. 16. Patskan, M.Yu. Orlov, A.M. Information support of technical support of ships at the first operation of the fleet. Software products and systems, 2000, №2. p. 40-42. 17. B. Fahimnia, L. Luong, R. Marian An integrated model for the optimization of a two-echelon supply network. Journal of Achievements in Materials and Manufacturing Engineering, 2008, Vol. 31 Issue 2 December. p. 477-484. 18. Ramírez Ríos, D. Ramírez Polo, L. Jimenez Barros, M. Castro Bolaño, L. Maldonado, E. The design of a real-time warehouse management system that integrates simulation and optimization models with RFID technology. International Journal of Computer Science \& Applications (TIJCSA), 2013, Vol. (02) No. (04). 19. Pratik J. Parikh, X.Z. and Bhanuteja S. Distribution planning considering warehousing decisions. [Electronic source]: Access mode: https://www.mhi.org/ downloads / learning / cicmhe / colloquium / 2010 / parikh.pdf 20. Yurov, B.N. Operations research. M .: VIA, 1990, 528 p. 21. Korolyuk V.S. Turbin, A.F. Semi-Markov processes and their applications. K .: Nauch. Mysl., 1976, 182 p. 22. Ivashchuk O.T. Economic and mathematical modeling: a textbook. Ternopil: TNEU "Economic Thought", 2008, 704 p. 23. Pavlenko P.M. Fundamentals of mathematical modeling of systems and processes: Tutorial. $\mathrm{K}$ : Book edition of NAU, 2013, 201 p. 24. Burimenko, Yu.I. Lebedeva, I.Yu. Shchurovskaya, A.Yu. Optimization methods and models with the solution of problems on the computer: textbook. allowance. Odessa, 2016, 152 p. 25. Tikhomirova, A.N. Sidorenko, EV. Mathematical models and methods in logistics: A textbook. M .: NIAU MEPhI, 2010, 320 p. 26. Stetsenko, I.V. Systems modeling: a textbook. Cherkasy: ChTTU, 2010, 399 p. 27. Matsenko V.G. Mathematical modeling: a textbook. Chernivtsi: Chernivtsi National University, 2014, 519 p. 28. Shvidanenko, G.O. Formation of the business model of the enterprise: a textbook. K $\therefore$ KNEU, 2013, 423 p. 29. Kolodizeva, T.O. Supply chain management: a textbook Kharkiv: KhNEU. S. Kuznets, 2016, 164 p. 30. Dachkovskyi, V.O. Kotsyuruba, V.I. Methods for assessing the effectiveness of the system of armaments and military equipment. Modern Information Technologies in the Sphere of Security and Defence, 2020, №1 (37), p. 5-14. DOI: 10.33099 / 2311-7249 / 2020-37-1-5-14 31. Dachkovskyi V.O. Methods of substantiation of tactical and technical requirements for movable means of repair of armaments and military equipment. Social development \& Security. $2019, \quad 9$ (6), 86-101. DOI: http://doi.org/10.33445/sds.2019.9.6.7

32. Dachkovskyi V.O. Methods of substantiation of tactical and technical requirements to the means of evacuation of weapons and military equipment. Social development \& Security. 2020, Vol. 10, no. 3, p. 104-113. DOI: 10.33445 / sds.2020.10.3.9 